\title{
Deep submarine landslide contribution to the 2010 Haiti earthquake tsunami
}

\author{
Adrien Poupardin ${ }^{1,2}$, Eric Calais ${ }^{2}$, Philippe Heinrich ${ }^{3}$, Hélène Hébert $^{3}$, Mathieu Rodriguez ${ }^{2}$, Sylvie Leroy $^{4}$, \\ Hideo Aochi ${ }^{2,5}$, and Roby Douilly ${ }^{6}$ \\ ${ }^{1}$ Institut de Recherche en Constructibilité, ESTP, Université Paris Est, Champ-sur-Marne, 77420, France \\ ${ }^{2}$ Ecole normale supérieure, Dept. of Geosciences, University PSL, CNRS, Paris, 75005, France \\ ${ }^{3}$ Commissariat à l'Energie Atomique, DAM, DIF, Arpajon, 91290, France \\ ${ }^{4}$ Université Pierre et Marie Curie, Sorbonne Universités, CNRS, ISTeP, Paris, 75005, France \\ ${ }^{5}$ Bureau de Recherches Géologiques et Minières, Orléans, 45000, France \\ ${ }^{6}$ Department of Earth Sciences, University of California, Riverside, 231, USA
}

Correspondence: Adrien Poupardin (apoupardin@estp-paris.eu)

Received: 19 November 2019 - Discussion started: 2 January 2020

Revised: 2 June 2020 - Accepted: 12 June 2020 - Published: 28 July 2020

\begin{abstract}
The devastating $M_{\mathrm{w}} 7.1$ Haiti earthquake in 2010 was accompanied by local tsunamis that caused fatalities and damage to coastal infrastructure. Some were triggered by slope failures of river deltas in the close vicinity of the epicenter, while others, 30 to $50 \mathrm{~km}$ to the north across the Bay of Gonâve, are well explained by the reverse component of coseismic ground motion that accompanied this mostly strike-slip event. However, observations of run-up heights up to $2 \mathrm{~m}$ along the southern coast of the island at distances up to $100 \mathrm{~km}$ from the epicenter, as well as tide gauge and DART buoy records at distances up to $600 \mathrm{~km}$ from the epicenter, have not yet received an explanation. Here we demonstrate that these observations require a secondary source, most likely a submarine landslide. We identify a landslide scar $30 \mathrm{~km}$ from the epicenter off the southern coast of Haiti at a depth of $3500 \mathrm{~m}$, where ground acceleration would have been sufficient to trigger slope failure in soft sediments. This candidate source, $2 \mathrm{~km}^{3}$ in volume, matches observations remarkably well assuming that the sediment collapse obeys a viscous flow with an initial apparent viscosity of $2 \times 10^{5} \mathrm{~Pa}$ s. Although that particular source cannot be proven to have been activated in 2010 , our results add to a line of evidence that earthquake-triggered submarine landslides can cause significant tsunamis in areas of strike-slip tectonic regime.
\end{abstract}

\section{Introduction}

The devastating $M_{\mathrm{w}} 7.1$ Haiti earthquake in 2010 occurred within the Caribbean-North America plate boundary, where oblique relative motion at $19 \mathrm{~mm} \mathrm{yr}^{-1}$ is partitioned between shortening on the North Hispaniola fault to the north and strike-slip motion on the E-W-striking Septentrional and Enriquillo faults throughout the island (Fig. 1; Symithe et al., 2015). Although the earthquake was first assumed to have occurred on the Enriquillo fault, several independent studies later showed that it actually ruptured a previously unmapped fault - the Léogâne fault - with a source mechanism combining strike-slip and reverse faulting (Calais et al., 2010; Hayes et al., 2010; Hashimoto et al., 2011; Symithe et al., 2013), in a setting resembling the 1989 Loma Prieta earthquake in California (e.g., Dietz and Ellsworth, 1990).

In spite of its moderate size and primarily strike-slip mechanism, the earthquake was accompanied by local tsunamis that caused at least three fatalities in Grand Goâve (Fritz et al., 2013) and some damage to coastal infrastructure. Thanks to the rapid deployment of an International Tsunami Survey Team (ITST), run-up height, flow depth and inundation were documented at more than 20 sites along the Haitian coastline (Fig. 1; Fritz et al., 2013). Maximum tsunami heights reached $3 \mathrm{~m}$ in the close vicinity of the earthquake epicenter in the bays of Petit Goâve and Grand Goâve along the northern coast of the southern peninsula, where the tsunami 


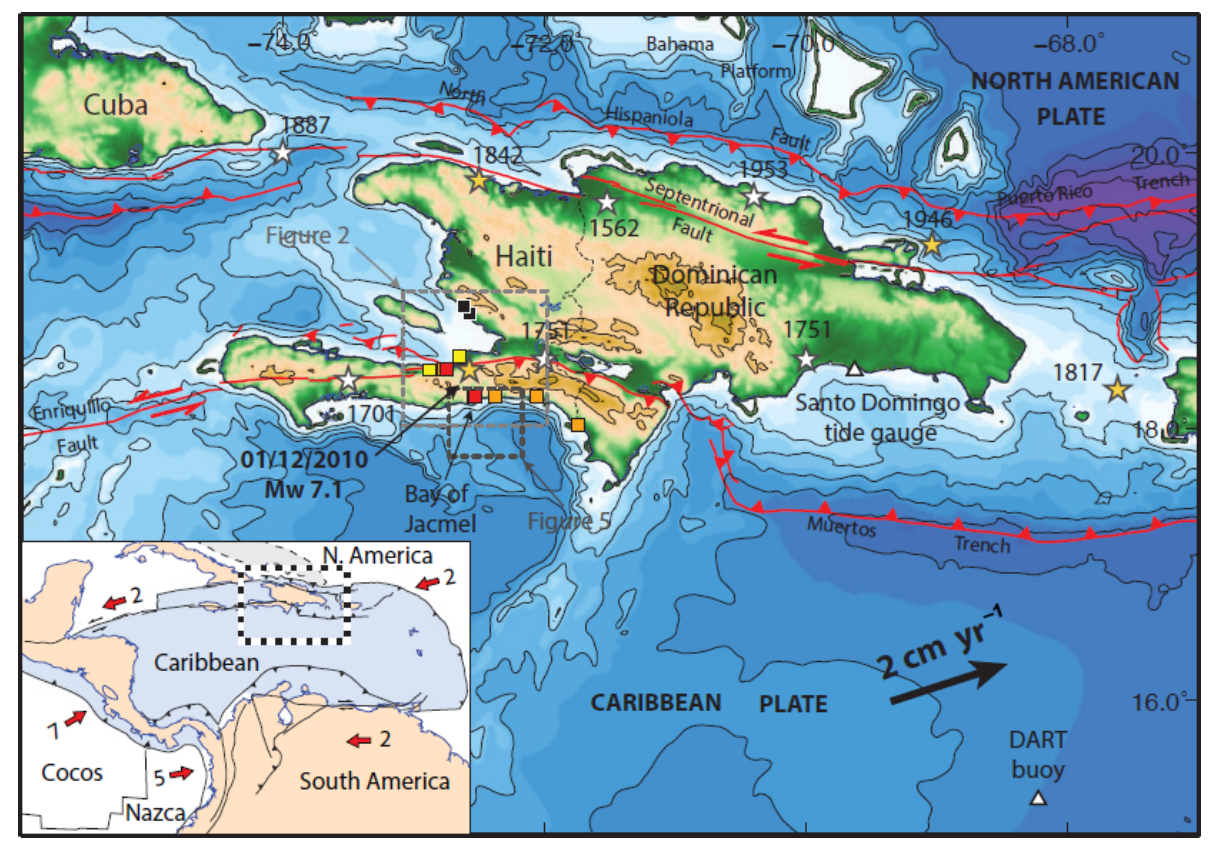

Figure 1. Regional tectonic context. The yellow star indicates the epicenter of the $2010, M_{\mathrm{W}} 7.1$ Haiti earthquake. Other yellow stars indicate the approximate epicenter of large historical tsunamigenic earthquakes, in particular the 1842 event of northern Haiti, which is discussed in the text. White stars show the approximate location of other large historical earthquakes. Tsunami run-up heights observed after the 2010 event are indicated by squares: < $1 \mathrm{~m}$ (yellow), 1 to $2 \mathrm{~m}$ (orange), $>2 \mathrm{~m}$ (red), draw down (black). The locations of DART buoy 42407 and the Santo Domingo tide gauge are indicated by white triangles. The inset shows the large-scale tectonic framework with current plate velocities relative to the Caribbean shown in centimeters per year.

was triggered by slope failures of river deltas (Hornbach et al., 2010; Fritz et al., 2013). A total of 30 to $50 \mathrm{~km}$ to the north across the Bay of Gonâve, eyewitnesses reported drawdown near the locality of Luly, well explained by the reverse component of the coseismic ground motion (Hornbach et al., 2010).

However, observations of run-up heights up to $2 \mathrm{~m}$ along the southern coast of Haiti, at distances up to $100 \mathrm{~km}$ from the epicenter, as well as tide gauge and DART buoy records at distances of 300 and $600 \mathrm{~km}$ from the epicenter, respectively, have not yet received a satisfactory explanation. Fritz et al. (2013), using the early source model from the National Earthquake Information Center (NEIC), were able to roughly match these observations by scaling coseismic slip by a factor of 4 while keeping a constant seismic moment, hence downscaling the regional rigidity coefficient. A similar ad hoc procedure was also proposed by Newman et al. (2011) for the 2010 Mentawai, Indonesia, earthquake in order to account for the discrepancy between coseismic slip inverted from teleseismic waves and actual slip derived from geodetic measurements. This artificially lowered rigidity can indeed account for slow ruptures at subductions - "tsunami earthquakes" (Kanamori, 1972) - such as in Mentawai in 2010 or in Java in 2006 (Hébert et al., 2012), but the Haiti earthquake fault ruptured at $2.6 \mathrm{~km} \mathrm{~s}^{-1}$, a regular rupture velocity (de Lépinay et al., 2011).
Here we revisit this issue by (1) testing most of the finitesource models proposed for the 2010 Haiti earthquake, (2) investigating the role that an earthquake-triggered landslide off the southern coast of Haiti may have played in tsunami generation. We show that this latter hypothesis is very likely, in line with the growing set of evidence linking tsunamis along strike-slip faults to submarine landslides (e.g., Ma et al., 1991; Yalçıner et al., 2002; Rodriguez et al., 2017).

\section{Tsunami calculation method}

The numerical method involves modeling of the initiation, propagation and run-up of the tsunami waves. For the earthquake source, we calculate the initial seafloor perturbation assumed to be instantaneously and fully transmitted to the water column - using coseismic static ground displacement for a dislocation in an elastic half-space (Okada, 1992). For the landslide source, we assumed that the sediment collapse obeys a viscous flow, consistent with the mud or shale nature of the sediments involved (Assier-Rzadkiewicz et al., 2000). We keep the dynamic viscosity constant during the whole simulation, which may not be realistic in terms of landslide propagation but has little effect on the free surface, which is mostly sensitive to the initial landslide acceleration (e.g., Løvholt et al., 2015; Poupardin et al., 2017). 
The tsunami propagation calculation accounts for dispersive terms in the deep ocean (Boussinesq equations) and neglects them near the coast (St Venant equations), retaining only the lowest-order nonlinear terms (Poupardin et al., 2018). In the latter case, we use a shock-capturing method to propagate strong nonlinear waves. In the former one, we use an iterative Crank-Nicholson method to solve the Boussinesq equations (details in Poupardin et al., 2017). Propagation equations are solved using a finite-difference scheme with a spatial discretization that uses centered differences for linear terms and forward differences for advection terms (Hébert et al., 2001).

We solve the numerical problem using four successive levels of nested bathymetric grids from the deep ocean to the local coastal areas of interest. The two lower-resolution grids use the GEBCO World Bathymetry with a resolution from 1600 to $400 \mathrm{~m}$. We digitized local bathymetric charts and included existing digital bathymetric data in the bays of Portau-Prince, Jacmel and Santo-Domingo to build local grids with a resolution of $25 \mathrm{~m}$ in order to accurately model nearshore resonance and amplification. We used the $1600 \mathrm{~m}$ resolution grid to propagate the tsunami to the DART Buoy and the $25 \mathrm{~m}$ one for the Santo Domingo tide gauge in order to account for resonance due to coastal bathymetry.

\section{Earthquake-generated tsunami}

We tested a uniform slip of $1 \mathrm{~m}$ using the NEIC fault geometry and rupture mechanism, as in Fritz et al. (2013; hereafter denoted the F model), as well as four finite-source models with variable coseismic slip derived from combinations of GPS, InSAR, coastal uplift and teleseismic data (Hayes et al., 2010; Meng et al., 2012; Symithe et al., 2013; Saint Fleur et al., 2015; hereafter denoted the H, M, S, and SF models, respectively). All finite-source models show that rupture occurred on a north-dipping blind fault (Léogâne fault) with two-thirds of the moment released by strike-slip motion and one-third by reverse motion, consistent with up to $60 \mathrm{~cm}$ of coastal uplift observed in the epicentral area (Hayes et al., 2010). The NEIC source model, based on teleseismic data only, shows the same coseismic motion partitioning, but on a south-dipping fault with a north-verging reverse component.

Static coseismic displacements from the finite-source models show up to $0.5-1 \mathrm{~m}$ of seafloor uplift north of the rupture (Fig. 2) and less than $0.01 \mathrm{~m}$ of subsidence along the southern coastline. The F model shows an opposite pattern because of its fault dip opposite to the finite-source models and larger coseismic displacement because of the ad hoc coseismic slip scaling factor applied (see above). This model is inconsistent with the coseismic geodetic observations and the coseismic coastal uplift observed in the epicentral area. It matches observations at the Santo Domingo tide gauge and DART buoy 42407 reasonably well in amplitude and period at low frequencies, but its coseismic slip was arbitrarily tuned to match these observations (Fig. 3).

All finite-source models predict a small tsunami in the epicentral area, with the $\mathrm{M}$ and SF models predicting wave heights of up to $1 \mathrm{~m}$ along more than $10 \mathrm{~km}$ of coastline length, inconsistent with the observations reported by the ITST team (Fritz et al., 2013). Indeed, coseismic coastal uplift in the M and SF models is larger and more spread out than the observations reported in Hayes et al. (2010). All finitesource models predict a local tsunami at Luly, with $0.5-1 \mathrm{~m}$ run-up height (Fig. 2), consistent with observations at that location (Hornbach et al., 2010). This local tsunami likely occurred as a result of the intersection of the coastline with the sharp edge of the bathymetric low that occupies most of the Bay of Port-au-Prince. Only the F model predicts significant wave heights along the southern coast (Fig. 4), but it also predicts run-up heights of $0.5-1 \mathrm{~m}$ in the highly populated and low-lying coastal region surrounding the capital city of Port-au-Prince that were not observed after the earthquake (Fig. 2).

That none of the finite-source models come close to the observations in the near field in Jacmel and Pedernales or in the far field at two locations $450 \mathrm{~km}$ apart likely indicates the presence of a secondary tsunami source. An offshore landslide comes to mind, as they are well known to trigger tsunamis even at large distances (e.g., Heinrich et al., 2001; Okal and Synolakis, 2004; Fritz et al., 2007; Hébert et al., 2012). Fritz el al. (2013) indeed already suspected that this type of source may be required to explain field observations near Jacmel and Pedernales.

\section{Landslide-generated tsunami}

We use a high-resolution bathymetry recently acquired offshore of the southern coast of Hispaniola (Leroy et al., 2015) to search for scars in the seafloor morphology that could be indicative of large submarine landslides within the area significantly shaken by the earthquake. The fact that the earthquake source approximately matches observed arrival times at the tide gauge and DART buoy is an indication that a possible landslide source should be located fairly close to the epicentral area, which is a requirement for seafloor acceleration to be sufficient to trigger slope failure.

We find the clearest and largest landslide signature $30 \mathrm{~km}$ due south of the tip of the cape that bounds the bay of Jacmel to the west, at a water depth of $3500 \mathrm{~m}$ (Fig. 5). The landslide is expressed on the seafloor by two arcuate scars at the slope break between a flat plateau (Haiti Plateau) marked by a sediment wave field and a narrow canyon likely feeding the northeastern corner of the $5000 \mathrm{~m}$ deep Haiti sub-basin (Mauffret and Leroy, 1999). The scar shows two horseshoeshaped lobes with sharp edges, opening to the east onto the narrow canyon that likely acted as an evacuation pathway for the sediments. Unfortunately, no chirp or high-resolution 


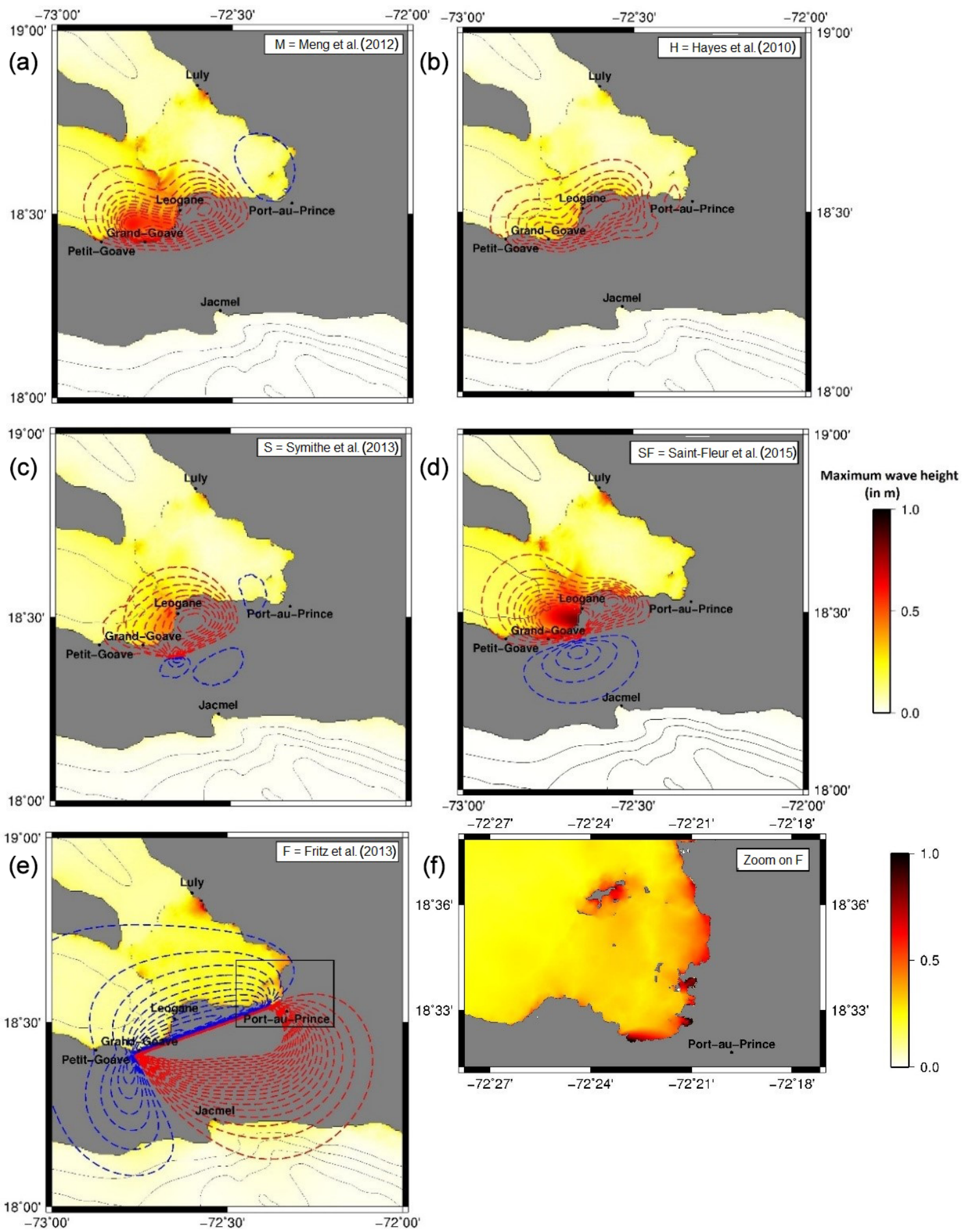

Figure 2. Initial coseismic seafloor displacement shown as dashed lines (red is uplift, blue is subsidence, and contours are shown every $0.05 \mathrm{~m}$ ) with maximum wave height shown as a colored map in the background in the near field of the 2010 Haiti earthquake. H: Hayes et al. (2010); M: Meng et al. (2012); S: Symithe et al. (2013); SF: Saint Fleur et al. (2015); F: Fritz et al. (2013). Calculations are done at a 30' bathymetric grid resolution. (f) Enlargement of the Port-au-Prince area for the F source model calculated using a $25 \mathrm{~m}$ resolution grid. 

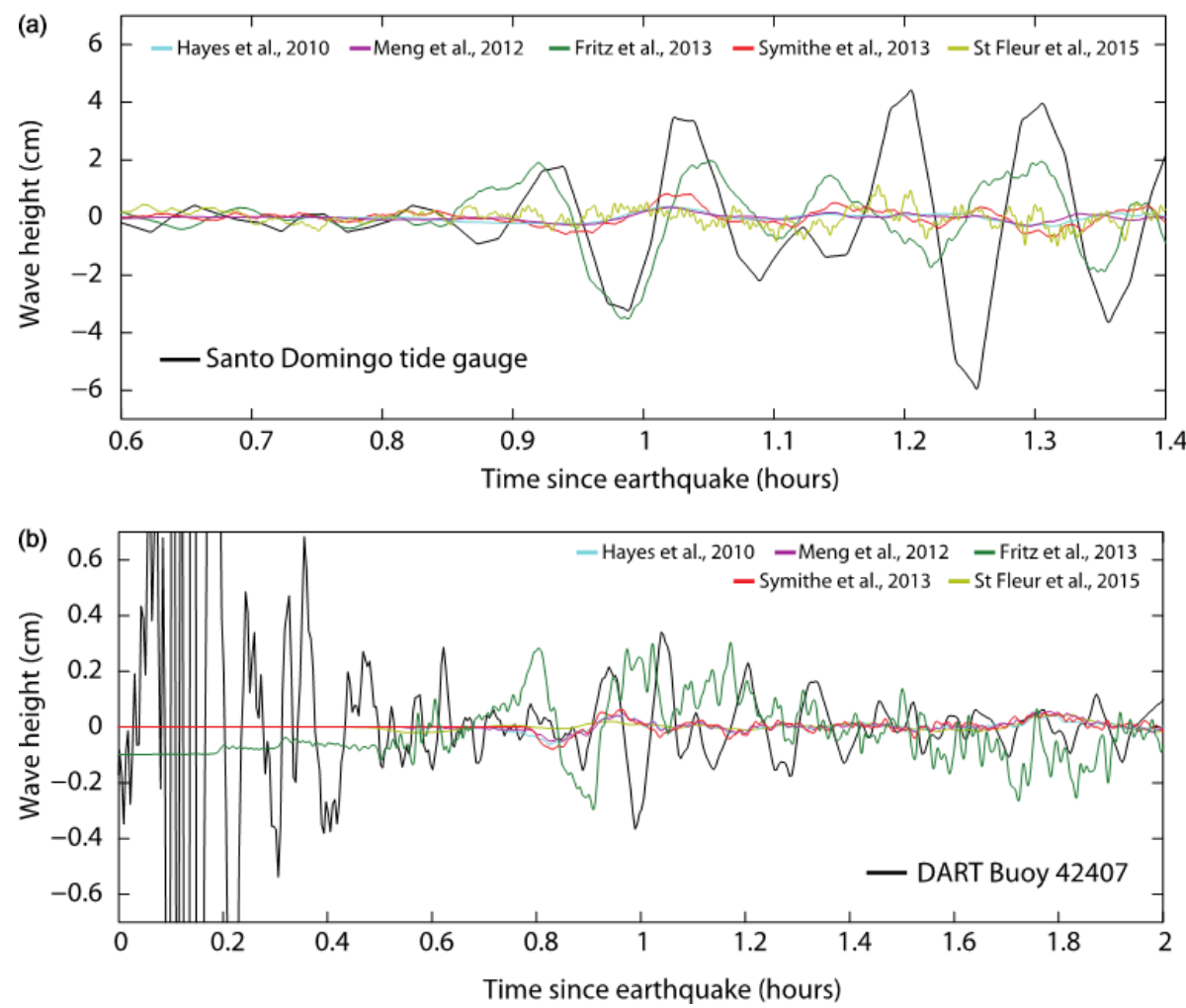

Figure 3. Comparison between observed and simulated water heights at the Santo Domingo tide gauge (a) and at DART buoy 42407 (b). Their locations are provided in Fig. 1. The high-amplitude signal on the DART record before $\sim 0.7 \mathrm{~h}$ is seismic surface waves.

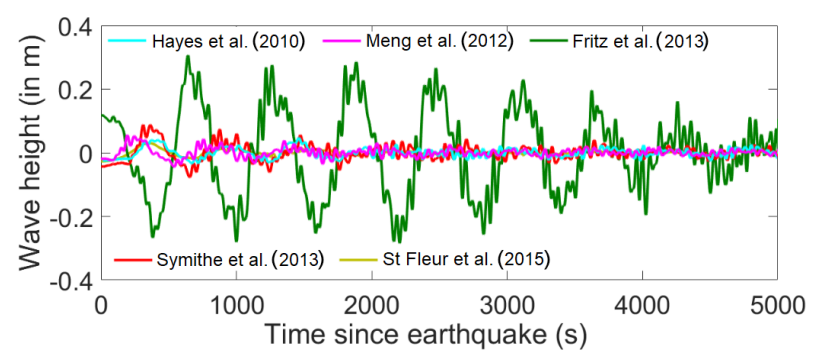

Figure 4. Water height comparison at a synthetic gauge located in the center of the Bay of Jacmel at $30 \mathrm{~m}$ water depth. Calculation on a bathymetric grid uses a 30 s resolution.

seismic data are available crossing that feature, which has not been cored either, so that one cannot determine the age of the sediment collapse. We try to identify the bathymetric scar using GEBCO grids, which contain data older than the 2010 Haiti earthquake, but we could not find any evidence for it. This could mean that the scarp is post-earthquake, but it could also mean that the resolution of the GEBCO data is insufficient to detect such a small-scale feature.

We test that landslide as the plausible secondary source necessary to explain the observations in the near field (southern coastline) and far field (tide gauge and DART buoy) of the earthquake. We use the detailed bathymetry (Fig. 5) to re- construct the sedimentary volume involved in the landslide, as in ten Brink et al. (2006). It consists of filling in the failed area according to the adjacent scar height, to reconstruct the seafloor morphology prior to the slide. By using this method, we find a volume of $2 \mathrm{~km}^{3}$, a maximum thickness of $150 \mathrm{~m}$, and a slope of $10^{\circ}$. Once triggered, the failed volume flows with maximum velocities in the $10-65 \mathrm{~m} \mathrm{~s}^{-1}$ range depending on the assumed viscosity (Fig. 6). The initial acceleration remains approximately the same at $\sim 0.5 \mathrm{~m} \mathrm{~s}^{-2}$ for all tested dynamic viscosities but it quickly decreases for the dynamic viscosity of $2 \times 10^{5} \mathrm{~Pa}$ s, resulting in smaller amplitudes within the model domain. The influence of the viscosity is evaluated by considering water heights calculated at a synthetic gauge located offshore, a few kilometers north of the landslide (gauge $\mathrm{G}_{1}$ in Fig. 8). As expected, the larger the viscosity, the smaller the amplitudes of water waves, whereas periods are unchanged (Fig. 7). The largest viscosity results in maximum wave amplitudes below $50 \mathrm{~cm}$ at the location of gauge $\mathrm{G}_{1}$.

In our preferred model, the southern coast of Haiti is reached by water waves within 5 to $10 \mathrm{~min}$ of the landslide triggering. Maximum water heights after $1 \mathrm{~h}$ of simulation (Fig. 8) show that water waves are amplified along an arc segment extending from the landslide area towards the Bay of Jacmel. The maximum wave heights reach 2 to $3 \mathrm{~m}$ along 

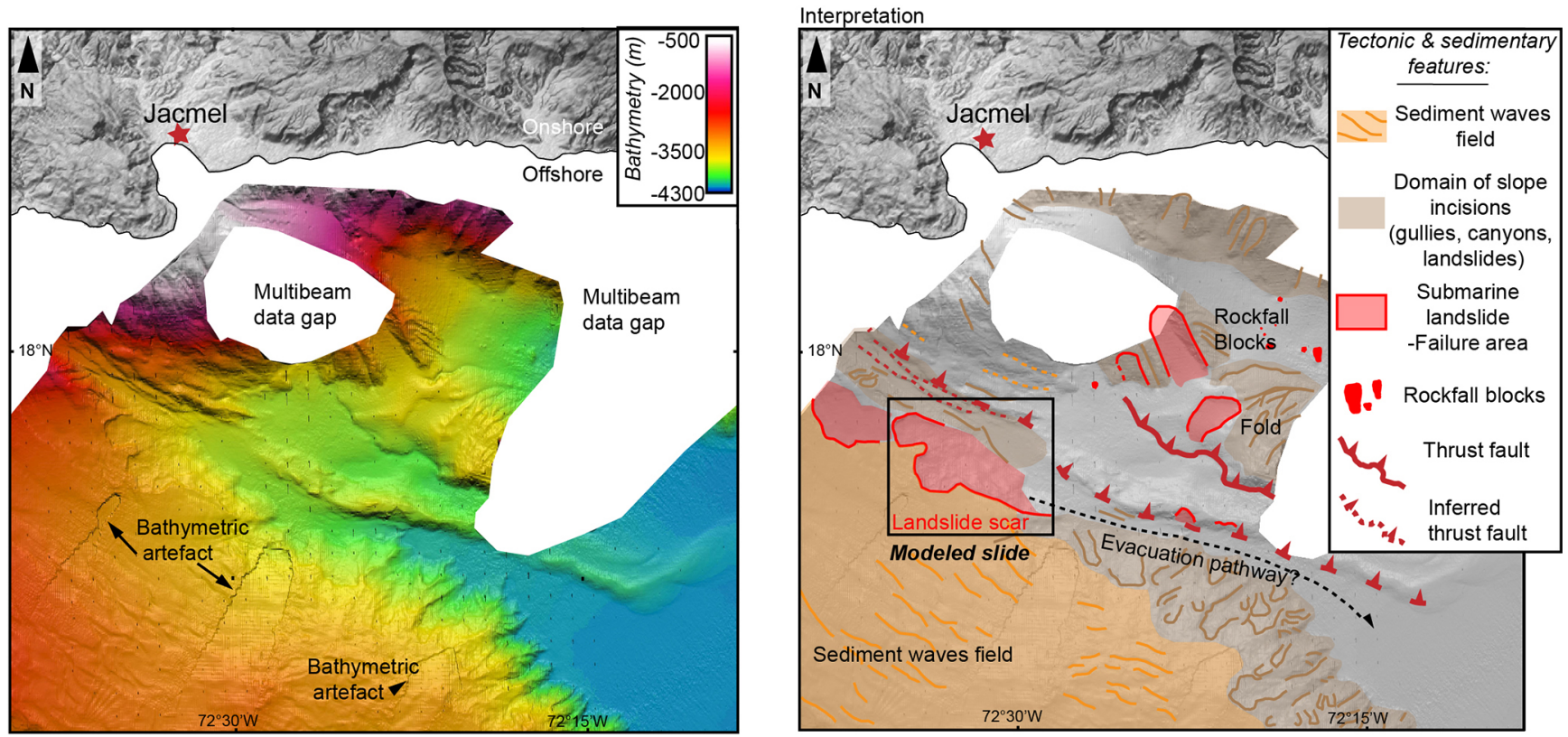

Figure 5. Detailed bathymetry $20 \mathrm{~km}$ due south of Jacmel (Fig. 1) where the landslide scar discussed in the text has been identified. (a) Raw observations. (b) Geological interpretation. Swath bathymetric data are from Haiti-sis cruise (https://doi.org/10.17600/12010070, Leroy, 2012). The white area corresponds to missing bathymetry of the boat campaign (Leroy et al., 2015).

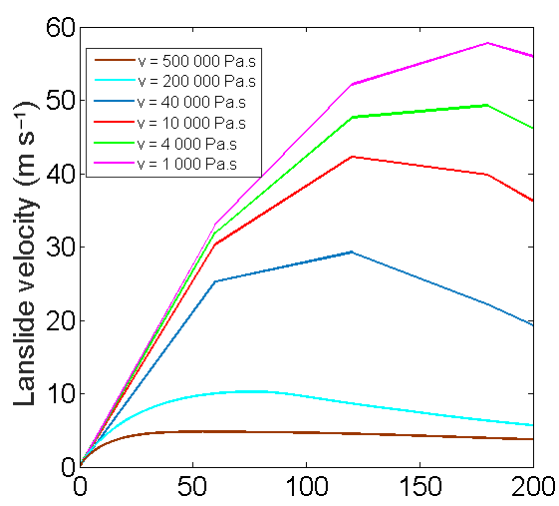

Figure 6. Landslide velocity as a function of time for the dynamic viscosities $v$ tested here.

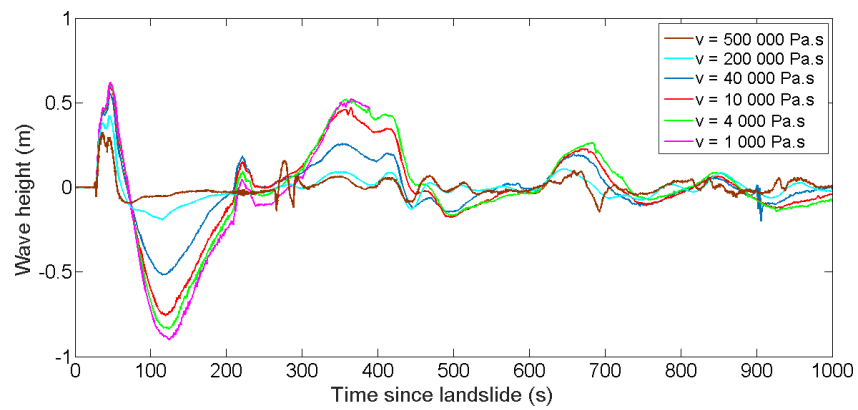

Figure 7. Time series calculated at the synthetic gauge $G_{1}$ as a function of time for the dynamic viscosities $v$ tested here.

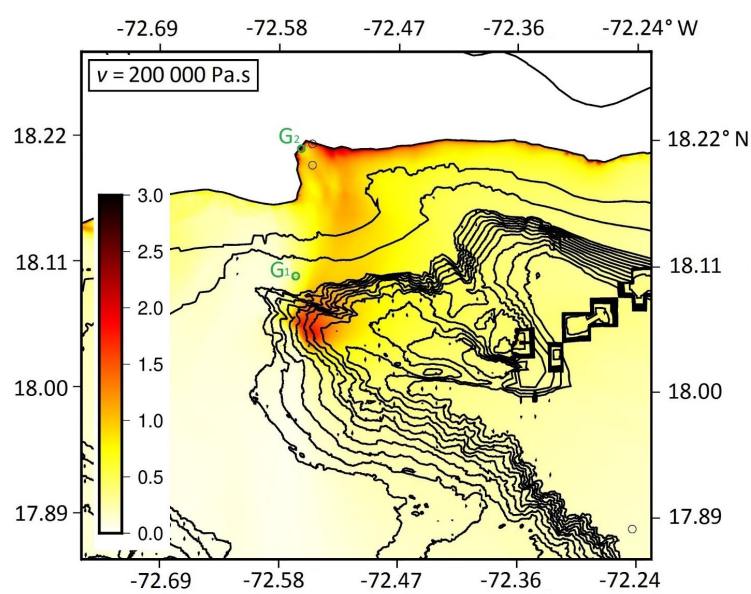

Figure 8. Maximum modeled wave height using a viscosity $v=$ $2 \times 10^{5} \mathrm{~Pa}$ s for the sliding material.

a coastal segment of $10 \mathrm{~km}$ for a viscosity of $2 \times 10^{5} \mathrm{~Pa} \mathrm{~s}$ (Fig. 8) consistent with ITST observations (Fritz et al., 2013).

Model results at synthetic gauge $\mathrm{G}_{2}$ located in the bay of Jacmel show that maximum wave amplitudes range from 3 to $6 \mathrm{~m}$ depending on the viscosity of the sliding material (Fig. 9). ITST measurements at Jacmel (see Fig. 5c in Fritz et al., 2013), around $3 \mathrm{~m}$, favor a sliding material with a viscosity in the high range of the ones tested here. Due to the local amplification of the bay, the maximum water height at Jacmel occurs $11 \mathrm{~min}$ after the underwater slope failure consistent with observations. 


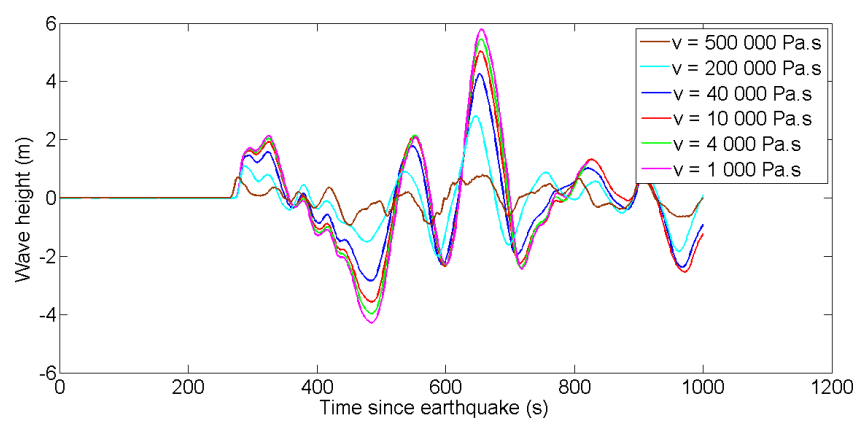

Figure 9. Time series calculated at synthetic gauge $\mathrm{G}_{2}$ located on the coast of the Bay of Jacmel (green circle in Fig. 8). This calculation uses a bathymetric grid with $25 \mathrm{~m}$ resolution.
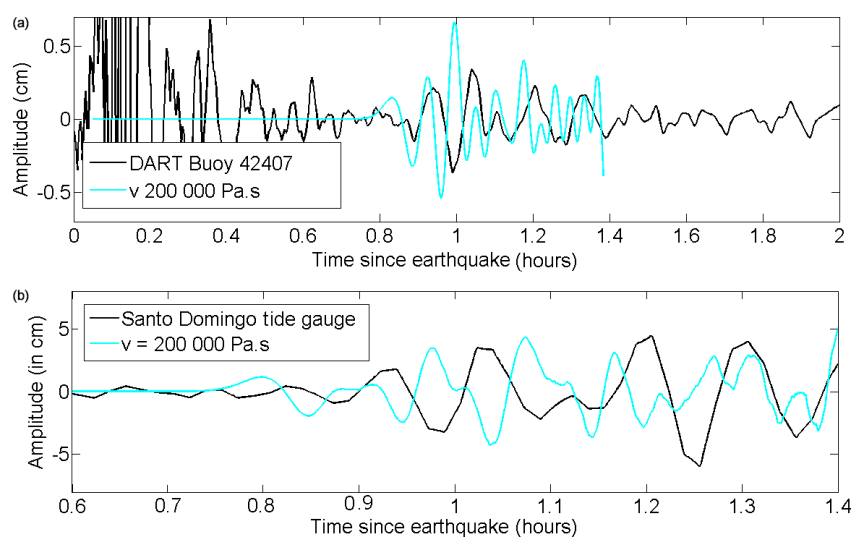

Figure 10. Comparison between observed and simulated water heights at the Santo Domingo tide gauge (a) and at DART buoy 42407 (b) for a dynamic viscosity $v=2 \times 10^{5}$ Pa s. High amplitudes observed before $0.6 \mathrm{~h}$ are due to the earthquake detected by the DART buoy.

Further along the coast, the comparison of calculated and observed time series at the Santo Domingo tide gauge is shown in Fig. 10. Data are available with a 1 min sampling rate and the tide gauge is located at the end of a small harbor that is poorly described in the simulation. Nevertheless, the arrival time of the first wave (about $45 \mathrm{~min}$ ) and the periods and amplitudes of water waves are approximately reproduced by the model. A time lag of 8 min exists between observations and simulations (Fig. 10), which could be explained by imprecisions of the tide gauge clock, a delay of the collapse triggering or imprecisions of the simulation due to errors in bathymetric data.

In the offshore direction, wave propagation is subject to frequency dispersion, which the model takes into account by solving Boussinesq equations. In Fig. 10, we compare the calculated time series with recorded data at DART buoy 42407 with a sampling rate of $1 \mathrm{~min}$. Due to frequency dispersion, the highest water height in the calculated wave train is not the first one but the third, with an amplitude of $0.5 \mathrm{~cm}$. The arrival times as well as amplitudes of the first two waves match the observed signal well. Nevertheless, the oscillations of the following waves (around $3 \mathrm{~min}$ ) have periods that are shorter than the observed ones (around $4 \mathrm{~min}$ ), which could indicate that the simulated landslide volume is insufficient to explain the observations.

\section{Discussion}

As a first verification, we checked that the landslide tested here, located $70 \mathrm{~km}$ from the epicenter, satisfied the magnitude-distance relationships proposed by Salamon and DiManna (2019). Then, we asked whether ground acceleration during the 2010 Haiti earthquake would be sufficient to trigger slope failure at the location of the earthquake described above. We estimate the resonance frequency of the landslide using $f=V_{\mathrm{s}} / 4 H$, where $V_{\mathrm{s}}$ is the shear-wave velocity and $H$ the landslide thickness (Parolai et al., 2002). For $V_{\mathrm{s}}=1000 \mathrm{~m} \mathrm{~s}^{-1}$ and $H=100 \mathrm{~m} f$ is $2.5 \mathrm{~Hz}$, a high-enough frequency to justify using peak ground acceleration (PGA) as a proxy for the acceleration that determines slope failure. It is generally recognized that $0.1-0.2 \mathrm{~g}$ PGA is the threshold of stability for the triggering of landslides in benthic sediments (e.g., Keefer, 1984; Meunier et al., 2007). Tanyaş et al. (2017) show that $80 \%$ of earthquake-induced terrestrial landslides are observed in the PGA interval $0.1-0.8 \mathrm{~g}$. Offshore, sedimentation rates, the state of sediment consolidation and the occurrence of weak layers determine the potential of seismic shaking to increase pore pressure up to the failure threshold. As a result, large PGA does not always trigger mass flow, whereas low PGA can sometimes be sufficient (Hampton et al., 1996; Viesca and Rice, 2012; ten Brink et al., 2016; Pope et al., 2017). For example, the study of Janin et al. (2019) on Holocene sediment collapses along the North Anatolian Fault in the Marmara Sea shows that water circulation induced by seismic shaking in the material can have a significant effect on landslide triggering.

There was no direct measurement of regional ground acceleration during the 2010 Haiti earthquake, but indirect estimates from rigid-body displacements and structural damage infer a PGA value of $0.2-0.4 \mathrm{~g}$ in Port-au-Prince (Olson et al., 2011; Goodno et al., 2011; Hough et al., 2012), $30 \mathrm{~km}$ east of the earthquake epicenter. A numerical ground motion study based on the coseismic slip distribution from Hayes et al. (2010) finds the mean PGA in Port-au-Prince to be 0.20-0.33 $g$ (Mavroeidis and Scotti, 2013). We computed a first-order estimate of the horizontal ground acceleration at the location of the offshore landslide described above using the "Next Generation Attenuation Ground Motions code" (Boore, 2012) for a $M 7$ earthquake (Fig. 11). We find PGA values on the order of $0.1 \mathrm{~g}$ at a distance of $30 \mathrm{~km}$ to the earthquake epicenter on soft rock (shear wave velocity near surface Vs30 of $530 \mathrm{~m} \mathrm{~s}^{-1}$ ). We also used the more precise, but more complex, approach based on a dynamic rupture simulation of the 2010 earthquake on a fault of realistic ge- 


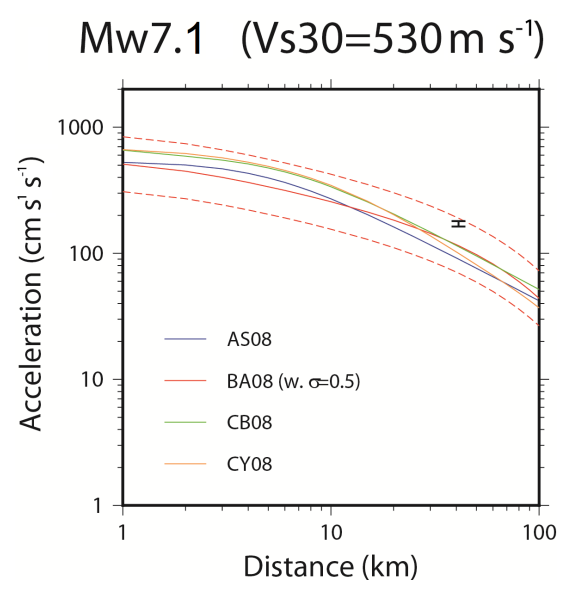

Figure 11. Estimated horizontal peak ground accelerations due to an earthquake of $M_{\mathrm{w}} 7.1$ from four ground motion prediction equations: Abrahamson and Silva (2008; blue line), Boore and Atkinson (2008; solid red line with \pm 1 standard deviation in dashed lines), Campbell and Bozorgnia (2008; yellow line), and Chiou and Youngs (2008; green line). The error bar symbol shows more accurate estimates derived from hybrid broadband ground acceleration calculation at the site of interest, as proposed in Douilly et al. (2017). This combines the deterministic low-frequency part from the dynamic rupture simulation of Douilly et al. (2015) with the stochastic high-frequency one calculated through the specific barrier model (Papageorgiou and Aki, 1983) for a crossover frequency of $1 \mathrm{~Hz}$.

ometry, as described in Douilly et al. (2015, 2017). Using the same source as these authors, which satisfies observations of static coseismic ground displacement, we find the largest horizontal peak ground acceleration at $0.18 \mathrm{~g}$ for the E-W component, while the mean horizontal peak ground acceleration is $0.17 \mathrm{~g}$ (Fig. 11). These two ground motion estimates are consistent with each other, though one must keep in mind that these calculations do not account for the more complex near-surface sediment structure likely to be present in the area of the submarine landslide.

Although there is no direct evidence that the submarine landslide described above was triggered by the 2010 Haiti earthquake, it appears that seafloor acceleration in that area was within the range that permits slope failure in marine sediments. It is therefore plausible that a submarine landslide off the southern coast of Haiti is the secondary source necessary to explain, at the same time, the far-field tide gauge and DART buoy observations and the exceptionally large run-up heights at a few locations along the southern coast of Haiti given the limited coseismic displacement there.

A number of similar examples have been documented, often in subduction contexts. For instance, the $1998, M_{\mathrm{w}} 7.0$ Papua New Guinea earthquake was followed by a tsunami with run-up heights of over $7 \mathrm{~m}$ on a $20 \mathrm{~km}$ long coastal segment, too large to be accounted for by the coseismic ground displacement alone (Okal and Synolakis, 2001; Tappin et al.,
2008). Numerical simulations showed that the tsunami could be attributed to a submarine landslide with a volume of $4 \mathrm{~km}^{3}$ located $20 \mathrm{~km}$ offshore (Heinrich et al., 2001). Similarly, the 2006 Java tsunami produced run-up heights up to $20 \mathrm{~m}$ at Permisan, indicative of a submarine landslide off the Nusa Kambangan Island (Fritz et al., 2007, Hébert et al., 2012). In the northern Caribbean, López-Venegas et al. (2008) argue that the tsunami associated with the 11 October 1918 $M_{\mathrm{w}} 7.5$ normal faulting earthquake in the Mona Passage between Hispaniola and Puerto Rico was the result of a submarine landslide at $\mathrm{a} \sim 2000 \mathrm{~m}$ depth. Run-up heights in western Puerto Rico reached up to $6 \mathrm{~m}$ about $20 \mathrm{~km}$ from the landslide, whose volume was estimated at $10 \mathrm{~km}^{3}, 5$ times that of the landslide described here. In a tectonic context similar to the 2010 Haiti earthquake, the $1989, M_{\mathrm{w}} 6.9$ Loma Prieta earthquake excited tsunamis in the nearby Monterey Bay that required a secondary offshore landslide, assumed to have occurred in shallow waters (Ma et al., 1991).

In northern Haiti, the $M_{\mathrm{w}} 7.6$ to 8.0, 7 May 1842 earthquake was followed by a tsunami that killed $\sim 300$ people, with wave heights of $2 \mathrm{~m}$ reported at a few locations along the northeastern Haitian coast and a maximum run-up of $4.6 \mathrm{~m}$ in the city of Port-de-Paix (Scherer, 1912). Some far-field effects have been reported, but their reliability remains questionable (O'Loughlin and Lander, 2003). Because it is the fastest-slipping active fault closest to the affected area, the Septentrional Fault is commonly assumed to be the source of that earthquake. However, a recent study shows that an 1842-like strike-slip earthquake on that fault cannot explain the tsunami run-up heights observed (Gailler et al., 2015). As a consequence, these authors suggest that event may have occurred on the North Hispaniola Fault, a slow-slipping reverse fault $\sim 50 \mathrm{~km}$ offshore. The MMI IX intensities estimated along the northern Haiti coastline for the 1842 earthquake suggest accelerations on the order of $0.3 \mathrm{~g}$ (Murphy and O'Brien, 1977). It is therefore plausible that a strike-slip event on the Septentrional Fault would have triggered submarine slope failures - possibly multiple ones - along the steep and near-shore slopes that characterize the bathymetry of the northern Haiti margin (Leroy et al., 2015).

Underwater mass movements have been suggested for more than 100 years to trigger tsunamis in the near field of large earthquakes (e.g., Verbeek, 1900; Gutenberg, 1939). They are now considered to be significant contributors to tsunami hazard (e.g., Synolakis et al., 2002; ten Brink et al., 2006; Okal et al., 2009). It has been noted that tsunamis in strike-slip tectonic regimes were more frequent than expected. Such events may be accompanied by submarine or subaerial landslides (e.g., Ma et al., 1991; Imamura et al., 1995; Yalçıner et al., 2002; Hornbach et al., 2010; Hoffman et al., 2014) or associated with a large coseismic deformation (Frucht et al., 2019). That local earthquakes can trigger shallow submarine slope failures is well known and was documented following the 2010 Haiti earthquake, in its epicentral area (Hornbach et al., 2010; Fritz et al., 2013). That deep 
submarine landslides can also produce significant tsunamis is less clear, though it was for instance proposed for the Puerto Rico, $M_{1} 7.5,1918$ earthquake and tsunami (López-Venegas et al., 2008).

Ten Brink et al. (2020) recently proposed that the tsunami observations described here were caused by a doublet of dynamically triggered aftershocks with magnitudes of $M 6.8$ and $M 6.5$ located $85 \mathrm{~km}$ southwest of the epicenter, with reverse faulting on south-dipping faults. We first note that these magnitudes are significantly larger than the M5.4 and 5.1 quoted in the original publication describing these aftershocks (Fan and Shearer, 2016). We computed the coseismic displacements that such large-magnitude events close to the coast would have caused at GPS sites onshore and found that they would have values (up to $5 \mathrm{~cm}$ in their preferred model) and directions (northward) that are not observed in the GPS data (Calais et al., 2010). Finally, our analysis of the detailed bathymetry and recently acquired seismic reflection profiles at the location of the alleged south-dipping reverse fault (Leroy et al., 2015) indicates that they are actually north-dipping. We therefore argue that the explanation proposed by ten Brink et al. (2020) does not hold in the face of the available data.

\section{Conclusion}

We have shown that observations of run-up heights up to $2 \mathrm{~m}$ along the southern coast of the Haiti at distances up to $100 \mathrm{~km}$ from the epicenter, as well as tide gauge and DART buoy records at distances up to $600 \mathrm{~km}$ from the 12 January 2010 epicenter, require a secondary source and can be explained by a submarine landslide. We have identified a landslide scar $30 \mathrm{~km}$ from the epicenter off the southern coast of Haiti at a depth of $3500 \mathrm{~m}$, where ground acceleration would have been sufficient to trigger slope failure in soft sediments. This candidate source, $2 \mathrm{~km}^{3}$ in volume, matches observations remarkably well assuming that the sediment collapse obeys a viscous flow with an initial apparent viscosity of $2 \times 10^{5} \mathrm{~Pa} \mathrm{~s}$. Although that particular source cannot be proven to have been activated in 2010, our results add to a line of evidence that earthquake-triggered submarine landslides can cause significant tsunamis in areas of strike-slip tectonic regime. This result contributes to explaining why many tsunamis occur along strike-slip fault systems, especially when steep submarine slopes are within reach of significant coseismic ground acceleration, as is the case along most strike-slip fault systems in the Caribbean.

Data availability. The bathymetric data are available on demand (Leroy, 2012).
Author contributions. AP, EC, $\mathrm{PH}$ and $\mathrm{HH}$ designed the study. AP and $\mathrm{PH}$ preformed the tsunami model calculations. SL acquired the bathymetric data, and SL and MR analyzed and interpreted the bathymetric data. HA and RD computed seismic ground motions. $\mathrm{AP}$ and EC led the manuscript writing. All co-authors contributed to the interpretation of the results and to the manuscript writing.

Competing interests. The authors declare that they have no conflict of interest.

Acknowledgements. The authors are grateful to colleagues from the Institut de Physique du Globe for sharing their source model for the 2010 Haiti earthquake.

Financial support. This research has been supported by the "Yves Rocard" joint laboratory between the Ecole Normale Supérieure, the Commissariat à l'Energie Atomique and the CNRS as well as by the Interreg Caraibes project PREST (European Union and FEDER) and the Institut Universitaire de France.

Review statement. This paper was edited by Maria Ana Baptista and reviewed by Frederic Dias and two anonymous referees.

\section{References}

Abrahamson, N. and Silva, W.: Summary of the Abrahamson \& Silva NGA Ground motion relations, Earthq. Spectra, 24, 67-97, 2008.

Assier-Rzadkiewicz, S., Heinrich, P., Sabatier, P., Savoye, B., and Bourillet, J. F.: Numerical modelling of a landslide-generated tsunami: the 1979 Nice event, Pure Appl. Geophys., 157, 1707$1727,2000$.

Boore, D. M.: NGA08_GM_TMR, Next generation attenuation ground motions for specified period $(T)$, magnitude, and distance (R) code, revised version, available at: http://www.daveboore. com (last access: May 2020), 2012.

Boore, D. M. and Atkinson, G. M.: Ground-motion prediction equations for the averaged horizontal component of PGA, PGV, and $5 \%$-damped PSA at spectral periods between $0.01 \mathrm{~s}$ and $10.0 \mathrm{~s}$, Earthq. Spectra, 24, 99-138, 2008.

Calais, E., Freed, A., Mattioli, G., Amelung, F., Jonsson, S., Jansma, P., Hong, S. H., Dixon, T., Prepetit, C., and Momplaisir, R.: Transpressional rupture of an unmapped fault during the 2010 Haiti earthquake, Nat. Geosci., 3, 794-799, 2010.

Campbell, K. W. and Bozorgnia, Y.: NGA Ground motion model for the geometric mean horizontal component of PGA, PGV, PGD and $5 \%$ damped linear elastic response spectra for periods ranging from 0.01 to $10 \mathrm{~s}$, Earthq. Spectra, 24, 139-171, 2008.

Chiou, B. S.-J. and Youngs, R. R.: An NGA model for the average horizontal component of peak ground motion and response spectra, Earthq. Spectra, 24, 173-215, 2008.

Dietz, L. D. and Ellsworth, W. L.: The October 17, 1989, Loma Prieta, California, Earthquake and its aftershocks: Geometry of the 
sequence from high-resolution locations, Geophys. Res. Lett., 17, 1417-1420, 1990.

Douilly, R., Aochi, H., Calais, E., and Freed, A.: Three-dimensional dynamic rupture simulations across interacting faults: The $M_{\mathrm{W}}$ 7.0, 2010, Haiti earthquake, J. Geophys. Res.-Sol. Ea. 120, 1108-1128, 2015.

Douilly, R., Mavroeidis, G. P., and Calais, E.: Simulation of broadband strong ground motion for a hypothetical $M_{\mathrm{W}} 7.1$ earthquake on the Enriquillo Fault in Haiti, Geophys. J. Int., 211, 400-417, 2017.

Fan, W. and Shearer, P. M.: Local near instantaneously dynamically triggered aftershocks of large earthquakes, Science, 353, 11331136, 2016.

Fritz, H. M., Kongko, W., Moore, A., Macadoo, B. G., Goff, J., Harbitz, C., Uslu, B., Kalligeris, N., Suteja, D., Kalsum, K., Titov, V., Gusman, A., Latief, H., Santoso, E., Sujoko, S., Djulkarnaen, D., Sunendar, H., and Synolakis, C.: Extreme runup from the 17 July 2006 Java tsunami, Geophys. Res. Letter, 34, L12602, https://doi.org/10.1029/2007GL029404, 2007.

Fritz, H. M., Hillaire, J. V., Molière, E., Wei, Y., and Mohammed, F.: Twin tsunamis triggered by the 12 January 2010 Haiti earthquake, Pure Appl. Geophys., 170, 1463-1474, 2013.

Frucht, E., Salamon, A., Gal, E., Ginat, H., Grigorovitch, M., Shem Tov, R., and Ward, S.: A Fresh View of the Tsunami Generated by the Dead Sea Transform, $1995 M_{\mathrm{W}} 7.2$ Nuweiba Earthquake, along the Gulf of Elat-Aqaba, Seismol. Res. Lett., 90, 14831493, 2019.

Gailler, A., Calais, E., Hébert, H., Roy, C., and Okal, E.: Tsunami scenarios and hazard assessment along the northern coast of Haiti, Geophys. J. Int., 203, 2287-2302, 2015.

Goodno, B., Gould, N., Caldwell, P., and Gould, P.: Effects of the January 2010 Haitian earthquake on selected electrical equipment, Earthq. Spectra, 27, S251-S276, 2011.

Gutenberg, B.: Tsunamis and earthquakes, B. Seismol. Soc. Am., 29, 517-526, 1939.

Hampton, M. A., Locat, J., and Lee, H. J.: Submarine landslides, Rev. Geophys., 34, 33-59, 1996.

Hashimoto, M., Fukushima Y., and Fukahata, Y.: Fan-delta uplift and mountain subsidence during the Haiti 2010 earthquake, Nat. Geosci., 4, 1-5, 2011.

Hayes, G. P., Briggs, R. W., Sladen, A., Fielding, E. J., Prentice, C., Hudnut, K., Mann, P., Taylor, F. W., Crone, A. J., Gold, R., Ito, T., and Simons M.: Complex rupture during the 12 January 2010 Haiti earthquake, Nat. Geosci., 3, 800-805, 2010.

Hébert, H., Heinrich, P., Schindelé, F., and Piatanesi, A.: Far-field simulation of tsunami propagation in the Pacific Ocean: impact on the Marquesas Islands (French Polynesia), J. Geophys. Res., 106, 9161-9177, 2001.

Hébert, H., Burg, P. E., Binet, R., Lavigne, F., Allgeyer, S., and Schindelé, F.: The 2006 July 17 Java (Indonesia) tsunami from satellite imagery and numerical modelling: a single or complex source?, Geophys. J. Int., 191, 1255-1271, 2012.

Heinrich, P., Piatanesi, A., and Hébert, H.: Numerical modeling of tsunami generation and propagation from submarine slumps: the 1998 Papua New Guinea event, Geophys. J. Int., 145, 97-111, 2001.

Hoffmann, G., Al-Yahyai, S., Naeem, G., Kociok, M., and Grützner, C.: An Indian Ocean tsunami triggered remotely by an on- shore earthquake in Balochistan, Pakistan, Geology, 42, 883886, 2014.

Hornbach, M. J., Braudy, N., Briggs, R. W., Cormier, M.-H., Davis, M. B., Diebold, J. B., Dieudonne, N., Douilly, R., Frohlich, C., Gulick, S. P. S., Johnson, H. E., Mann, P., McHugh, C., RyanMishkin, K., Prentice, C. S., Seeber, L., Sorlien, C. C., Steckler, M. S., Symithe, S. J., Taylor, F. W., and Templeton, J.: High tsunami frequency as a result of combined strike-slip faulting and coastal landslides, Nat. Geosci., 3, 783-788, 2010.

Hough, S. E., Taniguchi, T., and Altidor, J. R.: Estimation of peak ground acceleration from horizontal rigid body displacement: A case study in Port-au-Prince, Haiti, B. Seismol. Soc. Am., 102, 2704-2713, 2012.

Imamura, F., Gica, E., Takahashi, T., and Shuto, N.: Numerical Simulation of the 1992 Flores Tsunami: Interpretation of Tsunami Phenomena in Northeastern Flores Island and Damage at Babi Island, Pure Appl. Geophys., 144, 555-568, 1995.

Janin, A., Rodriguez, M., Sakellariou, D., Lykousis, V., and Gorini, C.: Tsunamigenic potential of a Holocene submarine landslide along the North Anatolian Fault (northern Aegean Sea, off Thasos island): insights from numerical modelling, Nat. Hazards Earth Syst. Sci., 19, 121-136, https://doi.org/10.5194/nhess-19121-2019, 2019.

Kanamori, H.: Mechanism of tsunami earthquakes, Phys. Earth Planet. In., 6, 346-359, 1972.

Keefer, D. K.: Landslides caused by earthquakes, Geol. Soc. Am. Bull., 95, 406-421, 1984.

Leroy, S.: HAITI-SIS cruise, RV L'Atalante, French Oceanographic Cruises, https://doi.org/10.17600/12010070, 2012.

Leroy, S., Ellouz-Zimmermann, N., Corbeau, J., Rolandone, F., de Lépinay, B. M., Meyer, B., Momplaisir, R., Granja Bruña, J. L., Battani, A., Baurion, C., Burov, E., Clouard, V., Deschamps, R., Gorini, C., Hamon, Y., Lafosse, M., Leonel, J., Le Pourhiet, L., Llanes Estrada, P., Loget, N., Lucazeau, F., Pillot, D., Poort, J., Tankoo, K. R., Cuevas, J. L., Alcaide, J. F., Jean Poix, C., MuñozMartin, A., Mitton, S., Rodriguez, Y., Schmitz, J., Seeber, L., Carbo- Gorosabel, A., and Muñoz, S.: Segmentation and kinematics of the North America-Caribbean plate boundary offshore Hispaniola, Terra Nova, 27, 467-478, 2015.

López-Venegas, A. M., ten Brink, U. S., and Geist, E. L.: Submarine landslide as the source for the October 11, 1918 Mona Passage tsunami: Observations and modeling, Mar. Geol., 254, 35-46, 2008.

Løvholt F., Pedersen, G., Harbitz, C. B., Glimsdal, S., and Kim, J.: On the characteristics of landslide tsunamis, Philos. T. Roy. Soc. A, 373, 20140376, https://doi.org/10.1098/rsta.2014.0376, 2015.

Ma, K. F., Satake, K., and Kanamori, H.: The origin of the tsunami excited by the 1989 Loma Prieta earthquake faulting or slumping?, Geophys. Res. Lett., 18, 637-640, 1991.

Mauffret, A. and Leroy, S.: Neogene intraplate deformation of the Caribbean plate at the Beata Ridge, Sedimentary Basins of the World, 4, 627-669, 1999.

Mavroeidis, G. P. and Scotti, C. M.: Finite-Fault Simulation of Broadband Strong Ground Motion from the $2010 M_{\mathrm{W}} 7.0$ Haiti Earthquake, B. Seismol. Soc. Am., 103, 2557-2576, 2013.

Meng, L., Ampuero, J. P., Sladen, A., and Rendon, H.: High-resolution backprojection at regional distance: Application to the Haiti M7.0 earthquake and comparisons 
with finite source studies, J. Geophys. Res., 117, B04313, https://doi.org/10.1029/2011JB008702, 2012.

de Lépinay, B. M., Deschamps, A., Klingelhoefer, F., Mazabraud, Y., Delouis, B., Clouard, V., Hello, Y., Crozon, J., Marcaillou, B., Graindorge, D., Vallée, M, Perrot, J., Bouin, M.-P., Saurel, J.-M., Charvis, P., and St-Louis, M.: The 2010 Haiti earthquake: A complex fault pattern constrained by seismologic and tectonic observations, Geophys. Res. Lett., 38, L22305, https://doi.org/10.1029/2011GL049799, 2011.

Meunier, P., Hovius, N., and Haines, A. J.: Regional patterns of earthquake-triggered landslides and their relation to ground motion, Geophys. Res. Lett., 34, L20408, https://doi.org/10.1029/2007GL031337, 2007.

Murphy, J. R. and O'Brien, L. J.: The correlation of peak ground acceleration amplitude with seismic intensity and other physical parameters, B. Seismol. Soc. Am., 67, 877-915, 1977.

Newman, A. V., Hayes, G., Wei, Y., and Convers, J.: The 25 October 2010 Mentawai tsunami earthquake from real-time discriminants, finite-fault rupture, and tsunami excitation, Geophys. Res. Lett., 38, L05302, https://doi.org/10.1029/2010GL046498, 2011.

Okada, Y.: Internal deformation due to shear and tensile faults in a half-space, B. Seismol. Soc. Am., 82, 1018-1040, 1992.

Okal, E. A. and Synolakis, C. E.: Comment on "Origin of the 17 July 1998 Papua New Guinea Tsunami: earthquake or landslide?", Seismol. Res. Lett., 72, 362-266, 2001.

Okal, E. A. and Synolakis, C. E.: Source discriminants for near-field tsunamis, Geophys. J. Int., 158, 899-912, 2004.

Okal, E. A., Synolakis, C. E., Uslu, B., Kalligeris, N., and Voukouvalas, E.: The 1956 earthquake and tsunami in Amorgos, Greece. Geophys. J. Int., 178, 1533-1554, 2009.

O'Loughlin, K. F. and Lander, J. F.: Caribbean Tsunamis: A 500Year History from 1498-1998, v.20, Springer, the Netherlands, 2003.

Olson, S. M., Green, R. A., Lasley, S., Martin, N., Cox, B. R., Rathje, E., Bachhuber, J., and French, J.: Documenting liquefaction and lateral spreading triggered by the 12 January 2010 Haiti earthquake, Earthq. Spectra, 27, S93-S116, 2011.

Papageorgiou, A. S. and Aki, K.: A specific barrier model for the quantitative description of inhomogeneous faulting and the prediction of strong ground motion. Part I. Description of the model, B. Seismol. Soc. Am., 73, 693-722, 1983.

Parolai, S., Bormann, P., and Milkereit, C.: New Relationships between Vs, Thickness of Sediments, and Resonance Frequency Calculated by the $H / V$ Ratio of Seismic Noise for the Cologne Area (Germany), B. Seismol. Soc. Am., 92, 2521-2527, 2002.

Pope, E. L., Talling, P. J., and Carter L.: Which earthquakes trigger damaging submarine mass movements: Insights from a global record of submarine cable breaks?, Mar. Geol., 384, 131-146, 2017.

Poupardin, A., Heinrich, P., Frère, A., Imbert, D., Hébert, H., and Flouzat, M.: The 1979 Submarine Landslide-Generated Tsunami in Mururoa, French Polynesia, Pure Appl. Geophys., 174, 32933311, 2017.

Poupardin, A., Heinrich, P. Hébert, H., Schindelé, F., Jamelot, A., Reymond, D., and Sugioka, H.: Traveltime delay relative to the maximum energy of the wave train for dispersive tsunamis propagating across the Pacific Ocean: the case of 2010 and 2015 Chilean Tsunamis, Geophys. J. Int., 214, 1538-1555, 2018.
Rodriguez, M., Maleuvre, C., Jollivet-Castelot, M., d'Acremont, E., Rabaute, A., Lafosse, M., Ercilla, G., Vázquez, J. T., Alonso, B., Ammar, A., and Gorini, C.: Tsunamigenic submarine landslides along the Xauen-Tofiño banks in the Alboran Sea (Western Mediterranean Sea), Geophys. J. Int., 209, 266-281, 2017.

Saint Fleur, N., Feuillet, N., Grandin, R., Jacques, E., Weil-Accardo, J., and Klinger, Y.: Seismotectonics of southern Haiti: A new faulting model for the 12 January 2010 M7.0 earthquake, Geophys. Res. Lett, 42, 10273-10281, 2015.

Salamon, A. and DiManna, P.: Empirical constraint son magnitudedistance relationships for seismically induced submarine tsunamigenic landslides, Earth-Sci. Rev., 191, 66-92, 2019.

Scherer, J.: Great earthquakes in the island of Haiti, B. Seismol. Soc. Am., 2, 161-180, 1912.

Symithe, S. J., Calais, E., Haase, J. S., Freed, A. M., and Douilly, R.: Coseismic Slip Distribution of the 2010 M7.0 Haiti Earthquake and Resulting Stress Changes on Regional Faults, B. Seismol. Soc. Am., 103, 2326-2343, 2013.

Symithe, S. J., Calais, E., Chabalier, J. B., Robertson, R., and Higgins M.: Current block motions and strain accumulation on active faults in the Caribbean, J. Geophys. Res., 120, 3748-3774, https://doi.org/10.1002/2014JB011779, 2015.

Synolakis, C. E., Bardet, J.- P., Borrero, J. C., Davies, H. L., Okal, E. A., Silver, E. A., Sweet, S., and Tappin, D. R.: The slump origin of the 1998 Papua New Guinea tsunami, P. Roy. Soc. Lond. A, 458, 763-789, 2002.

Tanyaş, H., Cees, J., van Westen, K. E., Allstadt, M. A., Nowicki, J., Tolga, G., Randall, W. J., Jonathan, W. G., Hiroshi, P. S., Robert, G. S., Odin, M., and Niels, H.: Presentation and Analysis of a Worldwide Database of Earthquake-Induced Landslide Inventories, J. Geophys. Res.-Earth, 122, 1991-2015, https://doi.org/10.1002/2017JF004236, 2017.

Tappin, D. R., Watts, P., and Grilli, S. T.: The Papua New Guinea tsunami of 17 July 1998: anatomy of a catastrophic event, Nat. Hazards Earth Syst. Sci., 8, 243-266, https://doi.org/10.5194/nhess-8-243-2008, 2008.

ten Brink, U. S., Geist, E. L., and Andrews, B. D.: Size distribution of submarine landslides and its implication to tsunami hazard in Puerto Rico, Geophys. Res. Lett., 33, L11307, https://doi.org/10.1029/2006GL026125, 2006.

ten Brink, U. S., Andrews, B. D., and Miller, N. C.: Seismicity and sedimentation rate effects on submarine slope stability, Geology, 44, 563-566, 2016.

ten Brink, U. S., Wei, Y., Fan, W., Granja Bruña, J.-L., and Miller, N.: Mysterious tsunami in the Caribbean Sea following the 2010 Haiti earthquake possibly generated by dynamically triggered early aftershocks, Earth Planet. Sc. Lett., 540, 116269, https://doi.org/10.1016/j.epsl.2020.116269, 2020.

Verbeek, R. D. M.: Kort verslag over de aarden zeebeving op Ceram, den 30sten September 1899, Natuurkundig Tijdschrift voor Nederlandsch-Indie, 60, 219-228, 1900.

Viesca, R. C. and Rice, J. R.: Nucleation of slip-weakening rupture instability in landslides by localized increase of pore pressure, J. Geophys. Res., 117, 255-21, 2012.

Yalçıner, A. C., Alpar, B., Altınok, Y., Özbay, I., and Imamura, F.: Tsunamis in the Sea of Marmara: Historical documents for the past, models for the future, Mar. Geol., 15, 445-463, 2002. 